\title{
Measurement of Social Technology Use in Islamic University Institutions in Indonesia (A Case Study)
}

\author{
$1^{\text {st }}$ Qurrotul Aini ${ }^{1}, 2^{\text {nd }}$ Nur Aeni Hidayah ${ }^{1}$ \\ \{qurrotul.aini@uinjkt.ac.id ${ }^{1}$,nur.aeni@uinjkt.ac.id ${ }^{1}$ \}
}

UIN Syarif Hidayatullah, Department of Information System, Jakarta, Indonesia ${ }^{1}$

\begin{abstract}
The advantage of utilizing social technology can help solve problems, improve the quality and quantity of communication with colleagues and students among universities, to save operational costs of the institution. However, negative impacts or risks that arise for organizations or individuals may happen if the use of this application is not managed properly and correctly. Universitas Islam Negeri Syarif Hidayatullah Jakarta (UIN Syahid) is one of the leading Islamic-based state higher education institutions in Indonesia. Measurement of technology use at UIN Syahid aimed to increase the distribution and ability of the academic community to obtain useful information. A survey has been conducted to collect data and analyzed them using descriptive statistics. While the measurement and hypothesis testing were conducted using partial least squares structural equation modeling (PLS-SEM). The survey results indicated that the average social technology users at UIN Syahid were used to using this application with about 6-10 years of experience and they routinely used this application to do work and professional development. The survey also showed that the majority of these application users intensely accessed this technology 5-7 times per week. The study results stated that the five variables, i.e. collaboration, communication, a frequency of access, knowledge \& resources sharing, and usefulness had a positive effect and significant correlation to the use of social technology. To improve the institutional performance, the management is expected to increase the socialization of the use of social technology applications, particularly for the new user group of this application.
\end{abstract}

Keywords: diffusion of innovation; partial least square; PLS-SEM; structural equation modeling; social technology.

\section{Introduction}

The application of social technology has become increasingly popular in recent years in various circles with different backgrounds/social groups. A study about social technology use in business-oriented and higher education institutions has been increased since 2008-2011 [1]. The simple reason why social technology is currently so popular both in business and in higher education institutions is that this application can be adopted free and can be easily used by various levels of social groups regardless of their educational background in the social system. This phenomenon has fundamentally changed the way of communication within individuals, social groups and organizational and institutional settings.

The use of social technology applications both individually and in groups around the world aims to engage in social activities such as interaction, collaboration, communication and sharing of knowledge resources [1]. 
The use of social technology applications both individually and institutionally faces two important issues, namely:

(i) users of this application will get various benefits

(ii) Adopters have not received the value of the benefits of social technology, and it can even bring risks that have a negative impact both individually and institutionally.

A study on the use of social technology has been done in different cross-country and cross-cultural contexts [1]. However, a study on social technology use in developing countries especially in higher education sectors is still rare. Competition among social technology users at the organizational level especially in the higher education sector is expected to continue to increase [1]. The adoption of social technology is generally used to assist institutions in increasing the competitiveness of each organization. The model used to measure the use of social technology in this study was derived from the theoretical framework and concepts of ref. [2] about the diffusion of innovation.

Most social technology users including higher education system in Indonesia do not focus on the potential of this use for the purpose of learning and teaching. The Islamic Higher Education Institution in Indonesia is part of the national higher education system in Indonesia. The total number of Islamic higher education (both public and private) reaches almost 15 percent of the total of national universities [3]. UIN Syahid as one of the leading Islamicbased state higher education institutions in Indonesia faces problems on how to measure the use of social technology to improve institutional competitiveness and variables used for measuring the adoption of social technology applications. Therefore, this study is as a pilot study for measuring social technology in universities by proposing a social technology use structure model involving several latent variables to obtain significance values.

\section{Related Work}

Higher education institutions as service-oriented organizations get benefits by adopting this social technology application. Social technologies (social tools) have been used by millions of people in the world for the purpose of communicating/collaborating, providing better customer services, opening new horizons, creating new awareness of the importance of good relationships with customers, building good relationships professionally, increasing marketing efforts, and recruiting new employees [4], [5]. Other studies on the same topic for the higher education sector in Romania showed that most students believed that sharing resources, collaborating through social networks online and communicating with instructors was very important [6]. This study concluded that communication had a significant influence on the potential use of social technology sites to carry out educational and teaching activities. In addition, there is a performance improvement for individuals or employees who use social technology to support their activities in an organizational context. Employees who use social technology can be integrated into their daily work resulting in effective communication between organizations and consumers. This study involves respondents across countries and cultures; therefore, other studies from various perspectives are indispensable. 
Higher education institutions must consider the positive and negative aspects of social technology applications to avoid certain risks. The negative aspect mostly discussed by scientists is the lack of a control mechanism for message content, time and frequency. The following is a model structure of social technology use at Islamic higher education institutions in Indonesia.

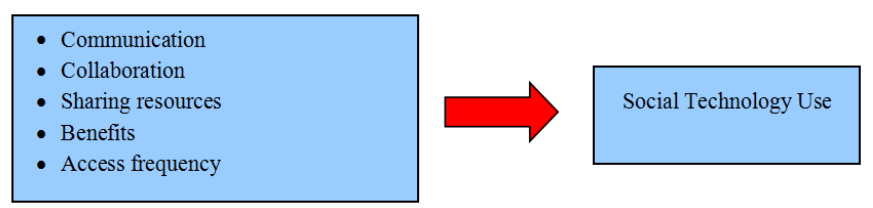

Figure 1. Social technology use

The model concept of social technology use can be seen in Fig. 1. In the model structure, five variables will influence social technology use. The five variables were adopted from a previous study, Technology Acceptance Model (TAM) [6], [7]. In recent years, the use of social technology applications has increased significantly around the world.

A qualitative study has been conducted by researchers to explore teacher service behavior, normative, and trust control referring to the desire to use web 2.0 technology in the classroom [8]. The study results showed that the majority, $51 \%$ of them, committed to web 2.0 technology as the main instructional tool because it could increase student involvement. Teachers realized that even though they were comfortable technology users, they needed guidance on how to apply their use effectively in class. By using a web-based questionnaire and interviewing students from four universities, ref. [9] found a large difference in students' perceptions of technology use between private spaces and learning spaces. While more than $70 \%$ of students report having a social networking account, they also indicate that they rarely use social media for educational purposes. Three of the five themes appeared in the interview can explain the reasons for "divide".

To date, several studies have investigated, such as some Islamic universities conducted a similar measurement of social technology usage. The investigations showed that students have a significant awareness of benefits, weakness, and role of social media/technology usage. Due to the intensity of social media usage cause dependency behavior [10-12].

\section{Research Method}

This study was conducted by applying quantitative methods in the form of survey strategies. Survey research provides quantitative or numerical descriptions of trends, attitudes, or opinions of a population by studying the population sample. This includes cross-sectional and longitudinal studies using questionnaires or structural interviews in data collection, aiming to generalize from sample to population [13], [14].

To ensure the chosen research model with the current phenomenon, this study proposes the overall reference of the research model used in this study, as illustrated in Fig. 2 and refer to a model of ref. [15]. 


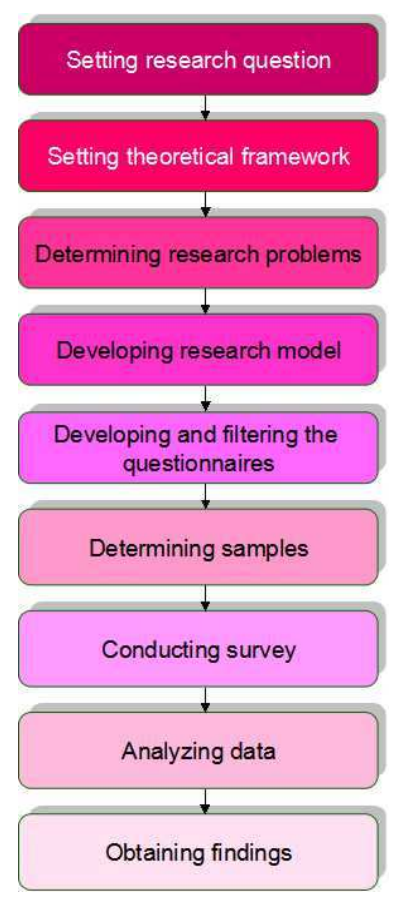

Figure 2. Overview of research design

The population of this study was in the environment of UIN Syahid as a representation of Islamic Higher Education Institution. Population samples were addressed to all users of social technology applications used at the university such as lecturers, students, and other faculty members such as non-lecturer staffs. The simple random sampling method was used in this study means that all samples in the population were equally likely to have the opportunity to be selected as respondents. An important benefit of simple random sampling is that it allows researchers to use statistical methods to analyze sample results. To get samples and data collection, several strategies had been implemented. Data were gathered through online and offline survey method. The online questionnaire was conducted by sending it via cell phone number or e-mail address to prospective respondents including a website link consisting of an explanation of the research, purpose, and contact number if there was a question to be asked.

Data were analyzed using descriptive statistics, such as percentages and frequencies to present the main characteristics of the sample and mean, and standard deviation. In this study, measurement methodology and hypothesis testing were assessed using partial least-square structural equation modeling (PLS-SEM). SEM is a modeling technique that can handle a large number of endogenous and exogenous variables and latent variables.

\section{Results}

Online questionnaires were distributed to three hundred potential respondents at Syarif Hidayatullah State Islamic University covering students, staff, and lecturers. However, those 
willing to fill it were 214 of them or only $71 \%$ of the expected target. Questionnaires were distributed in the form of hardcopy (offline) or soft copy (online through email or WhatsApp). In this study, students and lecturers dominated the majority of respondents. There were also some respondents as important personnel in the department, such as a head of department and secretary.

Descriptive analysis was conducted on the components/ items of all hypothesis variables. The results of descriptive variable analysis correlated with the dependent variable of social technology adoption that had been discussed before and other variables such as ease of use, usefulness, social influence, and facilitating conditions.

\subsection{Social Technology Adoption}

The concept of social technology adoption is measured by three items, namely: financial benefits, the effectiveness of communication and increasing individual performance. Table 1 shows the distribution of the three components in the parameters of mean, standard deviation, and minimum and maximum.

Table 1. Descriptive Statistics of Social Technology Adoption

\begin{tabular}{lllll}
\hline Item & Minimum & Maximum & Mean & Std. Deviation \\
\hline STE1- financial benefit & 2 & 5 & 3.89 & 0.856 \\
$\begin{array}{l}\text { STE2- effectiveness of } \\
\text { communication }\end{array}$ & 1 & 5 & 4.14 & 0.739 \\
$\begin{array}{l}\text { STE3- increasing the } \\
\text { individual performance }\end{array}$ & 2 & 5 & 3.89 & 0.849 \\
Average mean & & & 3.97 & \\
\hline
\end{tabular}

Table 1 shows the effectiveness of communication with the highest mean score (mean $=4.14, \mathrm{SD}=0.739)$. This highest rating may be attributed to personal placement related to effectiveness of communication, using social technology makes communication among peers more effective. This reflects financial benefit items with high mean (mean $=3.89$, SD = 0.859). This finding is also similar to the item of increasing individual performance which has a high mean score $($ mean $=3.89, \mathrm{SD}=0.849)$. The mean of these items is between 3.89 and 4.14. Most responses are a central tendency as standard deviation values that are closer to the mean.

\subsection{Usefulness}

This section discusses the usefulness (independent variables). There are four items as described in Table 2 to measure usefulness concepts.

Table 2. Descriptive Statistics of Usefulness

\begin{tabular}{lllll}
\hline Items & $\begin{array}{l}\text { Minimu } \\
\mathrm{m}\end{array}$ & $\begin{array}{l}\text { Maximu } \\
\mathrm{m}\end{array}$ & Mean & $\begin{array}{l}\text { Std. } \\
\text { Deviation }\end{array}$ \\
\hline $\begin{array}{l}\text { USE1 - help work } \\
\text { more effectively }\end{array}$ & 1 & 5 & 4.29 & 0.678 \\
$\begin{array}{l}\text { USE2 - easy to do } \\
\begin{array}{l}\text { academic work } \\
\text { USE3 - save time }\end{array}\end{array}$ & 1 & 5 & 4.18 & 0.698 \\
\hline
\end{tabular}




\begin{tabular}{lllll}
\hline $\begin{array}{l}\text { USE4 - useful for } \\
\text { academic work }\end{array}$ & 1 & 5 & 4.42 & 0.678 \\
Average mean & & & 4.33 & \\
\hline
\end{tabular}

Table 2 shows that the USE4 item has the highest mean score (mean $=4.42, \mathrm{SD}=0.678)$. This item has a score higher than the average mean score. While the lowest mean score is on USE2 item $($ mean $=4.18, \mathrm{SD}=0.698)$. This evidence indicates that higher education leaders must pay attention to providing training on how social technology can be used to support the work activities of respondents.

\subsection{Communication}

Communication variables can be measured from three items, as shown in Table 3.

Table 3. Description Statistics of Communication

\begin{tabular}{lllll}
\hline Item & $\begin{array}{l}\text { Minim } \\
\text { um }\end{array}$ & $\begin{array}{l}\text { Maximu } \\
\mathrm{m}\end{array}$ & $\begin{array}{l}\text { Mea } \\
\mathrm{n}\end{array}$ & $\begin{array}{l}\text { Std. } \\
\text { Deviati } \\
\text { on }\end{array}$ \\
\hline $\begin{array}{l}\text { COM1 - communication } \\
\text { with lecturers/peers }\end{array}$ & 1 & 5 & 4.42 & 0.672 \\
$\begin{array}{l}\text { COM2 - sharing of } \\
\text { academic information }\end{array}$ & 1 & 5 & 4.33 & 0.662 \\
$\begin{array}{l}\text { COM3 - communication } \\
\text { with colleagues in training }\end{array}$ & 1 & 5 & 4.10 & 0.724 \\
Average mean & & & 4.28 & \\
\hline
\end{tabular}

Table 3 indicates that COM1 item has the highest score $($ mean $=4.42, \mathrm{SD}=0.672)$. While the lowest score is COM3 item (mean $=4.10, \mathrm{SD}=0.724)$. This evidence shows that the communication built with colleagues with social technology is still not fully utilized.

\subsection{Collaburation}

Collaboration variables can be measured from three items as shown in Table 4 . Table 4 indicates that the COL1 item has the highest score (mean $=4.17$ and $\mathrm{SD}=0.650)$. While the lowest score is COL3 item (mean $=4.02$ and $\mathrm{SD}=0.712)$.

Table 4. Descriptive Statistics of Collaboration

\begin{tabular}{lllll}
\hline Item & $\begin{array}{l}\text { Minimu } \\
\mathrm{m}\end{array}$ & $\begin{array}{l}\text { Maximu } \\
\mathrm{m}\end{array}$ & Mean & $\begin{array}{l}\text { Std. } \\
\text { Deviatio } \\
\mathrm{n}\end{array}$ \\
\hline $\begin{array}{l}\text { COL1 - collaboration in } \\
\text { educational activities }\end{array}$ & 1 & 5 & 4.17 & 0.650 \\
$\begin{array}{l}\text { COL2 - collaboration } \\
\text { with colleagues about }\end{array}$ & 1 & 5 & 4.18 & 0.692 \\
$\begin{array}{l}\text { new ideas } \\
\begin{array}{l}\text { COL3 - collaboration } \\
\text { with colleagues in } \\
\text { project development }\end{array}\end{array}$ & 1 & 5 & 4.02 & 0.712 \\
\hline
\end{tabular}




\subsection{Knowledge and Resource Sharing}

Knowledge variables and resource sharing can be measured from two items as shown in Table 5.

Table 5. Descriptive Statistics of Knowledge and Resource Sharing

\begin{tabular}{|c|c|c|c|c|}
\hline Item & $\begin{array}{l}\text { Minimu } \\
\mathrm{m}\end{array}$ & $\begin{array}{l}\text { Maximu } \\
\mathrm{m}\end{array}$ & Mean & $\begin{array}{l}\text { Std. } \\
\text { Deviatio } \\
\mathrm{n}\end{array}$ \\
\hline KRS1 - share documents & 1 & 5 & 4.22 & 0.779 \\
\hline $\begin{array}{l}\text { KRS2 - share videos or } \\
\text { pictures }\end{array}$ & 1 & 5 & 4.24 & 0.721 \\
\hline Average mean & & & 4.23 & \\
\hline
\end{tabular}

Based on the descriptive analysis presented in Table 5, KRS2 item achieves the highest score $($ mean $=4.23$ and $\mathrm{SD}=0.721)$ and KRS1 item has a lower score $($ mean $=4.22$ and $\mathrm{SD}=$ 0.779). This evidence indicates that both items are similar and have not reached their maximum use of academic activities on campus for the respondents.

\subsection{Frequency of Access}

The frequency of the access variable can be measured from two items as shown in Table 6.

Table 6. Descriptive Statistics Frequency of Access

\begin{tabular}{lllll}
\hline Item & Minimum & Maximum & Mean & Std. Deviation \\
\hline $\begin{array}{l}\text { FOA1 - often } \\
\text { access increases } \\
\text { the effectiveness } \\
\text { of academic }\end{array}$ & 1 & 5 & 3.75 & 0.882 \\
$\begin{array}{l}\text { activities } \\
\text { FOA2 - often }\end{array}$ & 1 & & & \\
$\begin{array}{l}\text { access increases } \\
\text { academic } \\
\text { achievement }\end{array}$ & & 5 & 3.44 & 0.946 \\
Average mean & & & & \\
\hline
\end{tabular}

Referring to the results of Table 6 , the FOA1 item has the highest score (mean $=3.75$ and $\mathrm{SD}=0.882)$. While FOA2 item has a lower score $($ mean $=3.44$ and $\mathrm{SD}=0.946)$. This evidence indicates that the two items still cannot be ascertained about the impact on respondents.

\subsection{Social Technology Use}

The frequency of the access variable can be measured from three items as shown in Table 7. It shows the STU2 item has the highest score (mean $=4.19$ and SD $=0.720)$ and the lowest is STU3 item $($ mean $=3.94$ and $\mathrm{SD}=0.829)$.

Table 7. Descriptive Statistics of Social Technology Use 


\begin{tabular}{lllll}
\hline Item & $\begin{array}{l}\text { Minimu } \\
\mathrm{m}\end{array}$ & $\begin{array}{l}\text { Maximu } \\
\mathrm{m}\end{array}$ & $\begin{array}{l}\text { Mea } \\
\mathrm{n}\end{array}$ & $\begin{array}{l}\text { Std. } \\
\text { Deviatio } \\
\mathrm{n}\end{array}$ \\
\hline $\begin{array}{l}\text { STU1 - financial } \\
\text { benefits (saving } \\
\text { communication costs) }\end{array}$ & 1 & 5 & 3.96 & 0.801 \\
$\begin{array}{l}\text { STU2 - more } \\
\text { effective }\end{array}$ & 1 & 5 & 4.19 & 0.720 \\
$\begin{array}{l}\text { communication with } \\
\text { colleagues / lecturers }\end{array}$ & 1 & 5 & & \\
$\begin{array}{l}\text { STU3 - increased } \\
\text { personal performance }\end{array}$ & 1 & & 3.94 & 0.829 \\
Average mean & & & 4.03 & \\
\hline
\end{tabular}

This research model as shown in Fig. 3 is tested using Structural Equation Modeling (SEM), a statistical technique able to analyze the correlation pattern between latent variables and indicators, between latent variables themselves, and direct measurement errors. While the analysis tool used is the Smart-PLS version 2.0 application. The method of analysis conducted includes descriptive statistics and inferential statistics (outer and inner model tests).

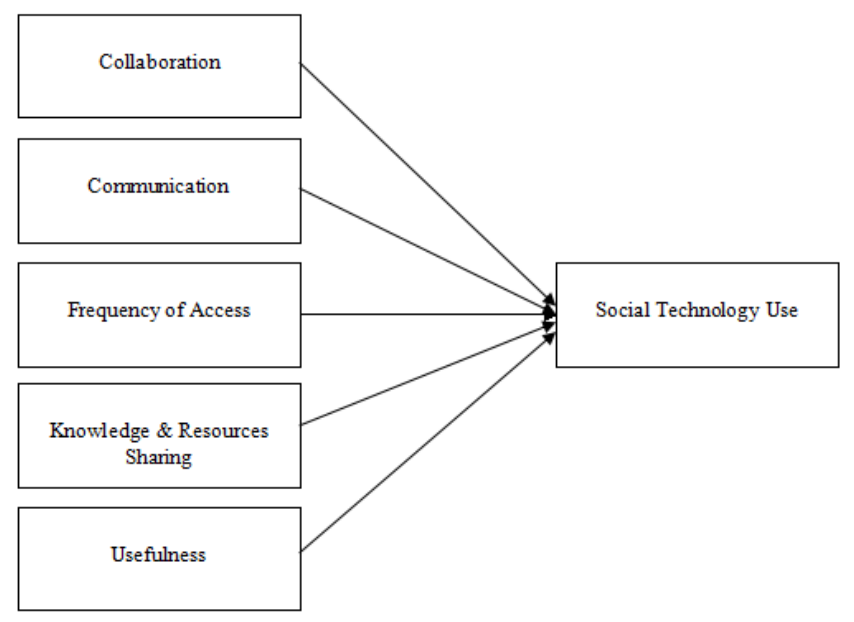

Figure 3. A proposed research model of social technology use

As seen in Fig. 4, the outer model measurement (measurement model evaluation) focuses on the reliability of indicators that can be assessed through absolute standards of loading factor, where the ideal value of a loading factor must be equal to or higher than 0.7 and significant at the level 0.05 . Figure 4 . shows that the results of calculations with the Smart-PLS 2.0 algorithm proves that all the 17 indicators used in this survey are all reliable. 


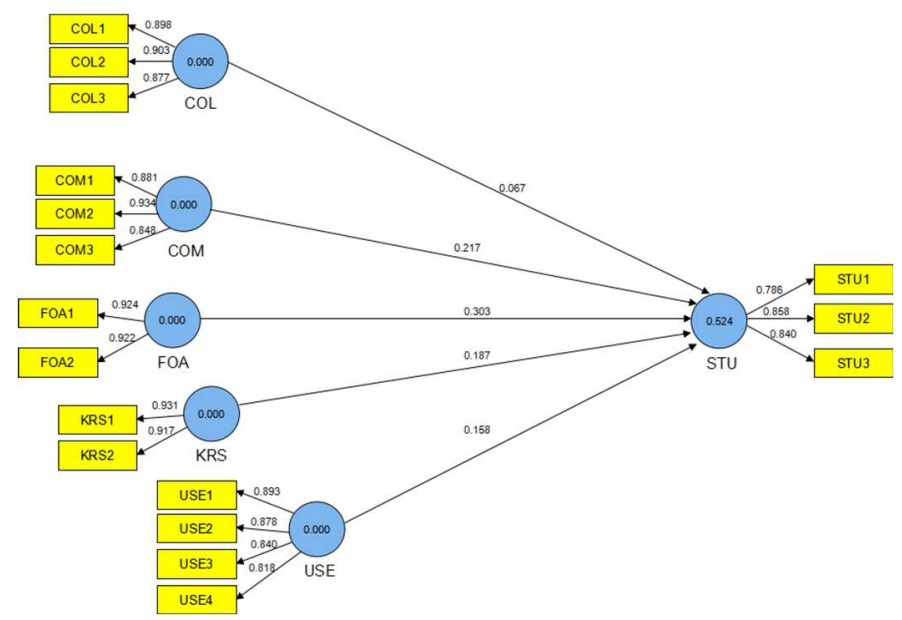

Figure 4. Structure of the research model

\section{Conclusions and Discussion}

The study results showed that the social technology application became a popular application and accepted in all levels such as students, lecturers, administrative staffs/ officials, groups of officials ranging from the level of the study program, dean office, rector office and bureau units at UIN Syahid. For groups based on age, it was revealed that young people (29 years and under) were the majority of users in this study. This is in line with the characteristics of the population of civitas academia members of the university where the student group is the majority. The average social technology user at the university is used to using this application with about 6-10 years experience. The evidence also indicates that social technology users routinely use this application to do work and professional development. As expected and predicted, the most popular social technology application among users are Facebook, Youtube and other applications like WhatsApp.

The study results also stated that the five variables, collaboration, communication, frequency of access, knowledge $\&$ resources sharing, and usefulness, have a positive effect and significant correlation to the use of social technology. To improve institutional performance, the management is expected to increase socialization and use of social technology applications, particularly for groups of newcomers who use this application. In reality, the management conducts socialization in the form of policies and adds new media in sharing information among civitas academia. The management will be more helpful if the application users are given training on how to use productive and efficient social technology to support teaching and learning activities for students, lecturers, staff and other groups. Utilization of social technology applications is maximized, especially sharing academic information.

In a study, there must be shortcomings or limitations, starting from approach method, sampling method used or from the other side such as the extent to which the contribution of the variables used in this research model is able to explain $52.4 \%$. The remaining, $47.6 \%$, is not accommodated in this research model, so something needs to be done to identify further 
research. Research with a quantitative method approach is vulnerable to the issue of generalization. Because of the limitations of existing samples, this study cannot be used to generalize globally. This study focuses on the population of social technology users among Higher Education institutions, particular in UIN Syahid. The number of questionnaire respondents affected the results of the study. With more respondents involved, the positive influence of variables will be clearly measured.

As mentioned in the related work, ref. [10] showed the response levels of Saudi and Jordanian students on Social Network Sites (SNSs) advantages and disadvantages using a questionnaire. Moreover, the results showed that Arabian students who use social networking websites are every 30 minutes rather than opening university or learning websites. Ref. [11] and [12] investigated the social technology for learning by questionnaire and statistical analysis. The analysis is done by obtaining frequency and percentage of Likert scale (strongly agreed until strongly disagreed). Compare with the current study, the author investigates a research model (inner and outer model) and measures the model variable to get a significant level of each indicator. This study not only results in measuring the use of social technology but recommend university which indicator that need improvement. Future research can involve many higher education institutions and can be applied in developing countries. Other influencing variables can be investigated and explored further.

Acknowledgements. The authors gratefully acknowledge the Center for Research and Community Services UIN Syahid for supporting financial and providing the guidance; and contributions made by several co-workers and colleagues in Department of Information System, M. Qomarul Huda, Ph.D., and Meinarini Catur Utami, MT.

This paper in conjuction with The 1st International Conference on Islam, Science and Technology (ICONIST 2018) in Malang, East Java.

\section{References}

[1] J. Bughin, A. H. Byers, and M. Chui, "How social technologies are extending the organization," McKinsey Quarterly: The Online Journal of McKinsey \& Company, November 2011. [Online], Available: http://www.mckinseyquarterly.com/How_social_technologies_are_extending_the_organization_2888. [Accessed August 8, 2018].

[2] E. M. Rogers, Diffusion of Innovation. New York: The Free Press, 1995.

[3] M. Buchori and A. Malik, "The evolution of higher education in Indonesia," in Asian Universities: Historical Perspectives and Contemporary Challenges, P. G. Altbach and T. Umakoshi, Eds. Baltimore: Johns Hopkins University Press, 2004, pp. 249-277.

[4] J. H. Nord, J. Paliszkiewicz, and A. Koohang, "Using social technologies for competitive advantage: Impact on organizations and higher education," Journal of Computer Information Systems, vol. 55, no. 1, pp. 92-104, 2014.

[5] S. Klososky, Enterprise Social Technology: Helping Organizations Harness the Power of Social Media, Social Networking, Social Relevance. Austin, Texas: Greenleaf Book Group Press, 2011.

[6] A. Stanciu, F. Mihai, and O. Aleca, "Social networking as an alternative environment for education," Accounting \& Management Information Systems/Contabilitate si Informatica de Gestiune, vol. 11, no. 1, pp. 56-75, 2012. 
[7] F. D. Davis, "Perceived Usefulness, Perceived Ease of Use, and User Acceptance of Information Technology,” MIS Quarterly, vol. 13, no. 3, pp. 319-340, 1989.

[8] A. Sadaf, T. J. Newby, and P. A. Ertmer, "Exploring pre-service teachers beliefs about using Web 2.0 technologies in K-12 classroom," Computers \& Education, vol. 59, no. 3, pp. 937-945, 2012.

[9] N. Jones, H. Blackey, K. Fitzgibbon, and E. Chew, "Get out of My Space!," Computers \& Education, vol. 54, no. 3, pp. 776-782, 2010.

[10] H. Mohammad and H. Tamimi, "Student's Perception of Using Social Networking Websites for Educational Purpose: Comparison between Two Arab Universities," International Journal of Managing Information Technology (IJMIT), vol. 9, no.2, pp. 13-26, May 2017.

[11] I. Hussain, O. Cakir, and U. Candeger, "Social Media as a Learning Technology for University Students," International Journal of Instruction, vol. 11, no. 2, pp. 281-296, April 2018.

[12] M. Oueder and I. Abousaber, "A Study on the Impact of Social Media Usage on Student Academic Performance: University of Tabuk an Example," American Scientific Research Journal for Engineering, Technology, and Sciences (ASRJETS), vol. 40, no. 1, pp. 77-88, 2018.

[13] U. Sekaran and R. Bougie, Research Methods for Business: A Skill Building Approach, 5th Edition. Hoboken: John Wiley and Sons Inc., 2009.

[14] J. W. Creswell, Research Design: Qualitative, Quantitative, and Mixed Methods Approaches, 3rd Ed. California: Sage Publications Inc., 2009.

[15] M. Q. Huda, M. C. Utami, N. A. Hidayah, and Q. Aini, "Effective IT Governance in Higher Education Institutions: The Conceptual Model," Advances in Intelligent Systems Research (AISR), vol. 149, pp. 148-151, 2018. 